\title{
Relationship between Concentration and Discharge on Storm Events: Case Study at Cakardipa Catchment, Cisukabirus Subwatershed, Upper Ciliwung Watershed, Bogor, West Java
}

\author{
Nani Heryani ${ }^{1}$, Hidayat Pawitan ${ }^{2}$, Mohamad Yanuar Jarwadi Purwanto ${ }^{2}$ and Kasdi Subagyono ${ }^{3}$ \\ ${ }^{1}$ Indonesian Agroclimate and Hydrology Research Institute (IAHRI), Agency for Agricultural \\ Research and Development. Jl. Tentara Pelajar No. 1A, Bogor 16111, Indonesia. \\ Telp./fax:+62-251-8312760,e-mail:heryani_nani@yahoo.com \\ ${ }^{2}$ Bogor Agricultural University, Darmaga Campuss, Bogor, Indonesia \\ ${ }^{3}$ Indonesian Center for Agricultural Technology Assesment and Development, Bogor, Indonesia
}

Received 10 October 2011 / accepted 3 January 2012

\begin{abstract}
River nutrient loadings rates are frequently determined from discharge and hydrochemistry relationships using regression techniques. Unfortunately such methods as a conventional technique are inadequate for dealing with the problem such as differences in shape and direction of loop forming in individual and seasonal storms. Besides the relationships are nonlinear and time-dependent, they also varies from site to site. There is a currently method to study hysteresis between discharge and concentration of hydrochemistry. The relationship between discharge and solute concentration was investigated at Cakardipa catchment, Upper Ciliwung watershed, between the years of 2009-2010. The characteristics of the hysteresis loops were used to evaluate the temporal variation of the relative contribution to stream flow of source waters at Cakardipa Catchment including groundwater $\left(\mathrm{C}_{\mathrm{G}}\right)$, soil water $\left(\mathrm{C}_{\mathrm{SO}}\right)$, and rain water $\left(\mathrm{C}_{\mathrm{R}}\right)$. Chemical water analysis was carried out on 497 water samples on storm event. The chemical analysis of storm event of Februari 14, 2010 was carried out for the concentrations of $\mathrm{K}^{+}, \mathrm{Ca}^{2+}, \mathrm{Mg}^{2+}, \mathrm{Na}^{+}, \mathrm{SiO}_{2}, \mathrm{SO}_{4}^{2-}$ $\mathrm{NO}_{3}^{-}, \mathrm{Cl}^{-}$, and $\mathrm{HCO}_{3}^{-}$. Results of the experiment showed that cconcentrations displayed circular hysteresis loops during the events, highlighting the complex relation among solutes and discharge during storm hydrographs. The solutes of $\mathrm{K}, \mathrm{Na}$, and Ca produced concave curvature, anti-clockwise hysteresis loops, and positive trend, so that classified as $\mathrm{A}_{2}$ loops with components ranking were $\mathrm{C}_{\mathrm{R}}>\mathrm{C}_{\mathrm{G}}>\mathrm{C}_{\mathrm{SO}}$ The solutes of $\mathrm{Mg}, \mathrm{SO}_{4} \mathrm{NO}_{3}$ assumed to come from groundwater produced convex curvature, clockwise hysteresis loops, and positive trend, indicating a concentration component ranking of $\mathrm{C}_{\mathrm{G}}>\mathrm{C}_{\mathrm{R}}>\mathrm{C}_{\mathrm{SO}}\left(\mathrm{C}_{2}\right.$ model). While $\mathrm{Si}$ and $\mathrm{Cl}$ produced clockwise hysteresis loops, indicating a concentration component ranking of $\mathrm{C}_{\mathrm{G}}>\mathrm{C}_{\mathrm{SO}}>\mathrm{C}_{\mathrm{R}}$ which was $\mathrm{C}_{1}$ model.
\end{abstract}

Keywords: Discharge, hydrochemistry, hysteresis, storm event

\section{INTRODUCTION}

There is a dynamic relationship between discharge and solute concentration during a storm event in a catchment area (Evans et al. 1998). This relationship may be represented in a circular pattern that is called a C/Q hysteresis loop. More studies have shown that $\mathrm{C} / \mathrm{Q}$ hysteresis analysis is rarely linear, and that it tends to produce a circular pattern from the differing concentrations on the rising and falling limbs (Walling and Webb 1986). The pattern of the relationship between discharge and concentration is circular because the total concentration levels of solutes vary during different periods of a storm. The variation in concentration

J Trop Soils, Vol. 17, No. 1, 2012: 85-95

ISSN 0852-257X is the product of dilution and "end-member mixing (the mixing of the different components of discharge, which are quantities of water from multiple sources).

Evans and Davies (1998) and Evans et al. (1999) showed that the characteristics of the hysteresis loops analyses were used to determine which end-member of the discharge, groundwater, soil water, or surface event water, predominates among the three, and in where in the hydrograph it was present in its greatest amount. Besides that, this technique uses the temporal variations in stream tracer concentrations with respect to stream discharge along with approximate tracer concentrations which are supplied by each component to show hysteresis between the rising and falling limbs of the hydrograph. Surface runoff dominates the early storm event on the rising limb, is followed by the contribution of soil water, and that ground water dominates the flow on the 
hygrograph's falling limb. It has been shown that a system can follow the pattern of surface runoff, soil water, and then groundwater dominance, as stated above, but that storm events can be dominated by different sequences of water contributions.

Identification of nutrient flushing mechanisms at the catchment scale is essential for model development and prediction of land use change and climate change effects on surface water quality. Understanding the flushing mechanism during storm events is important, since stormflow contributes substantially to total DOC and nitrogen $(\mathrm{N})$ export (Hinton et al. 1997; Bernal et al. 2006).

Different solutes were associated with the sources of different end-members of discharge, and the concentration levels of particular solutes were utilized in developing the hysteresis loops for this study. The solutes measured for this study were: $\mathrm{K}^{+}, \mathrm{Ca}^{2+}, \mathrm{Mg}^{2+}, \mathrm{Na}^{+}, \mathrm{SiO}_{2}, \mathrm{SO}_{4}^{2-}, \mathrm{NO}_{3}^{-}$, and $\mathrm{Cl}^{-}$.
The aims of this study were to describe the characteristics of end-member mixing of a small catchment using a graphic representation of hysteresis, and to explain the mechanisms that control the majority results of the hysteresis loops.

\section{MATERIALS AND METHODS}

\section{Study Area}

The study was conducted from June 2009 to April 2010 in Cakardipa catchment, Cisukabirus subwatershed, Upper Ciliwung watershed, Bogor, West Java. This is a catchment of 60.8 ha from the total area of Cisukabirus subwatershed of 1,749 ha. The altitude of the catchment ranges from $300 \mathrm{~m}$ to 700 $\mathrm{m}$ asl, with slightly steep slopes (about $21 \%$ ) over the wetland zone, steep slopes (40\%) over the wet and dry land, and very steep slopes (39\%) over the

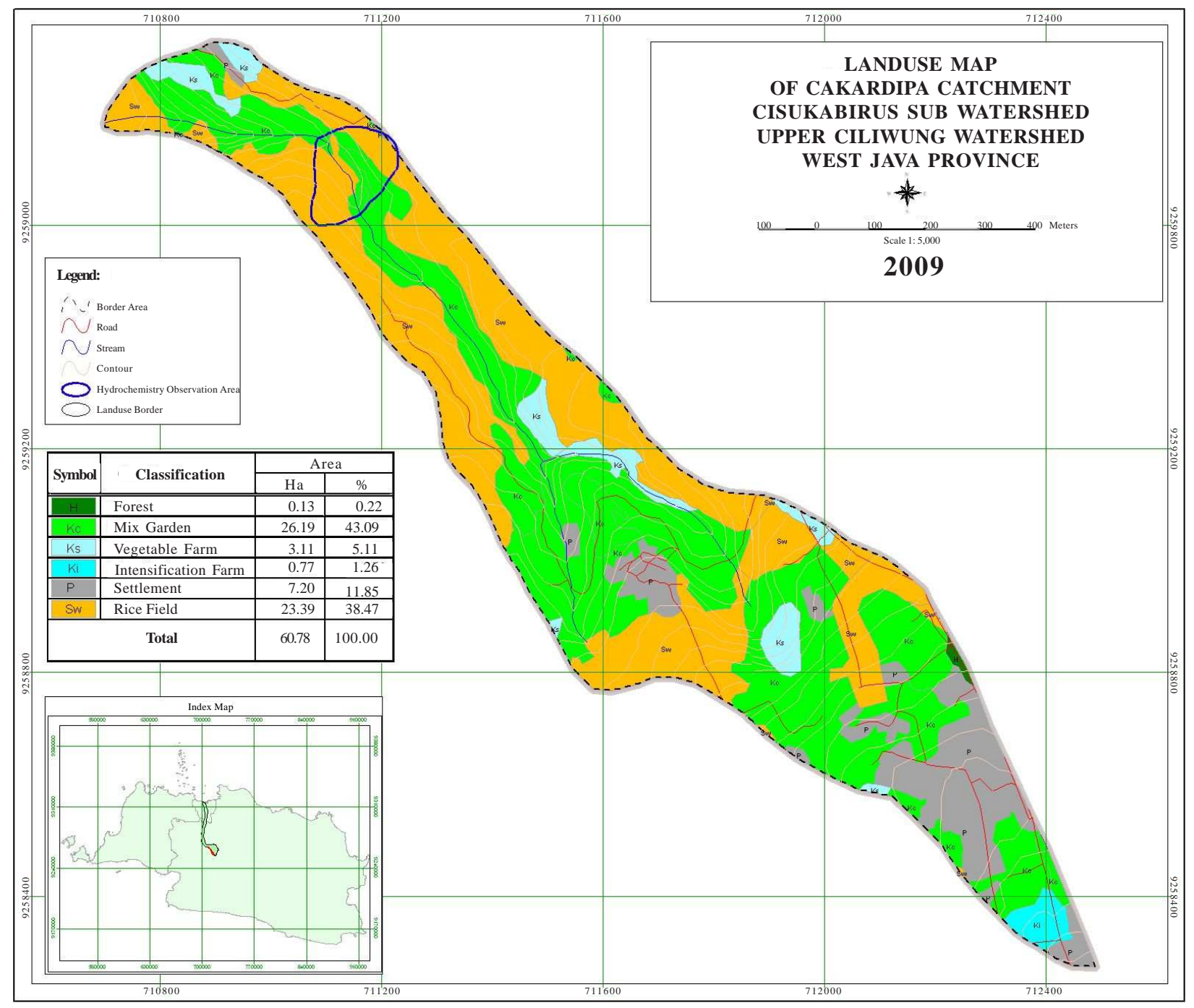

Figure 1. Landuse of Cakardipa catchment, Cisukabirus Sub-watershed, Upper Ciliwung Watershed, Bogor, West Java. 
hillslope area. The soil types of this area consists of Fluvaquentic Endoaquepts, Fluventic Dystrudepts, Fluvaquentic Endoaquepts, Typic Hapludands, and Aquic Dystrudepts. The main landuse of this area were a mix garden, a paddy field, and settlement about $43 \%, 38 \%$, and $12 \%$, respectively (Figure 1). The annual precipitation was about 2,735-3,687 mm with the mean annual was $3,077 \mathrm{~mm}$. The dry month (precipitation $<100 \mathrm{~mm}$ ) was about 2-4 month, while the wet month (precipitation $>200 \mathrm{~mm}$ ) is about 68 month.

\section{Hydrometric and Hydrochemistry Measurements}

A transect across hillslope along the flow line was nested with piezometers, tensiometers, and suction samplers with various depths to monitor the dynamic of subsurface flow and chemical pathways depicted in Figure 2, and spatially in Figure 3. Discharge was continuously recorded with AWLR (Automatic Water Level Recorder) installed at downstream of the northern valley of the catchment. Water level at weir was automatically recorded using a data logger that was set for every 5 minutes interval recording. Rainfall was measured using HOBO type of ARR (Automatic Rainwater Recorder) placed about $1 \mathrm{~km}$ from the experimental site.

A partly perforated piezometer was used, which was a PVC tube with a diameter of $5 \mathrm{~cm}$ and a bottom perforation length of $10 \mathrm{~cm}$. A PVC cup was complemented at the top of piezometer for hammering, and the rest of about $20 \mathrm{~cm}$ remains
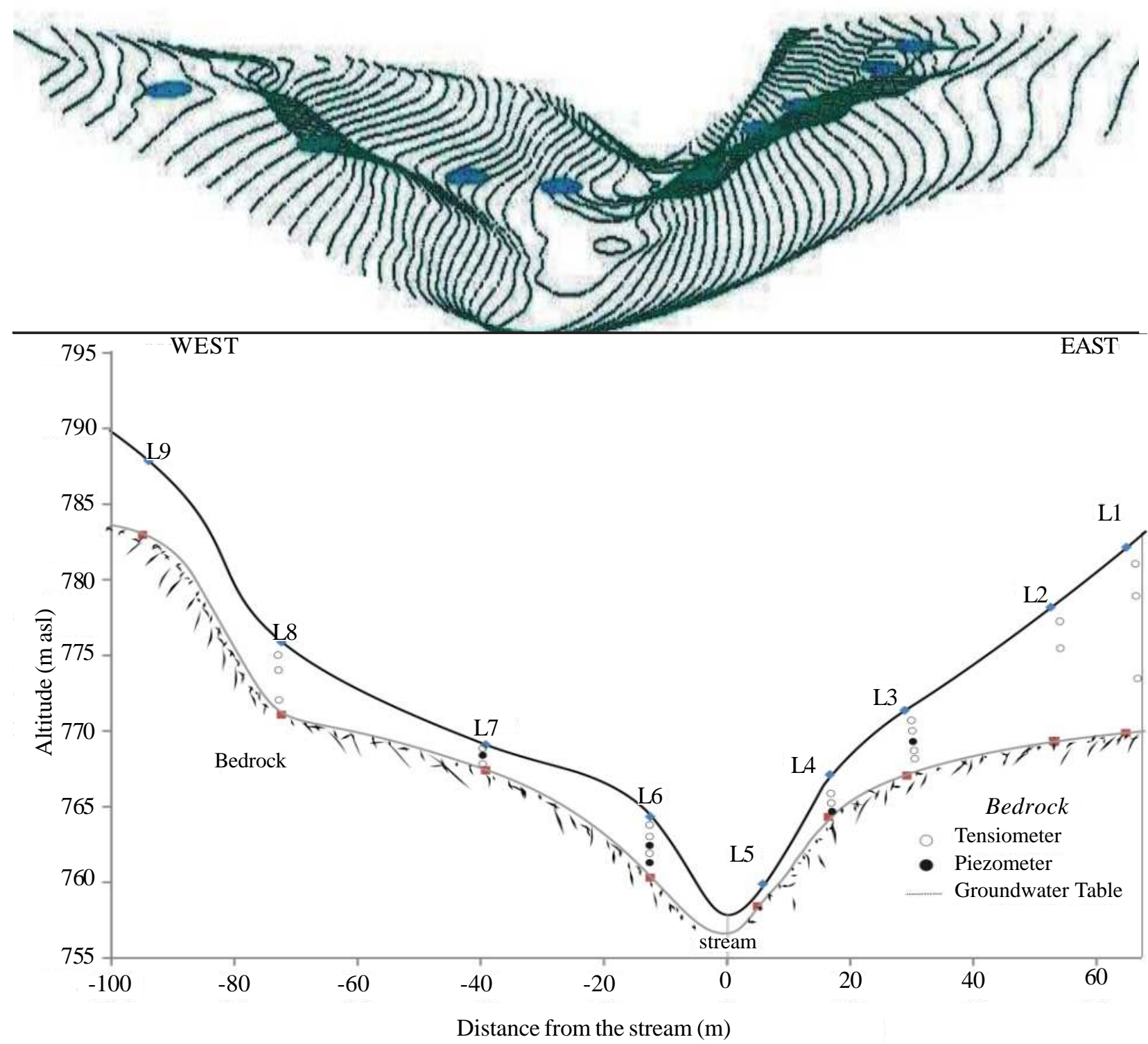

Figure 2. The transect showing the nests of piezometers, tensiometers, and suction samplers at Cakardipa catchment, Cisukabirus Sub-watershed, Upper Ciliwung Watershed, Bogor, West Java. 


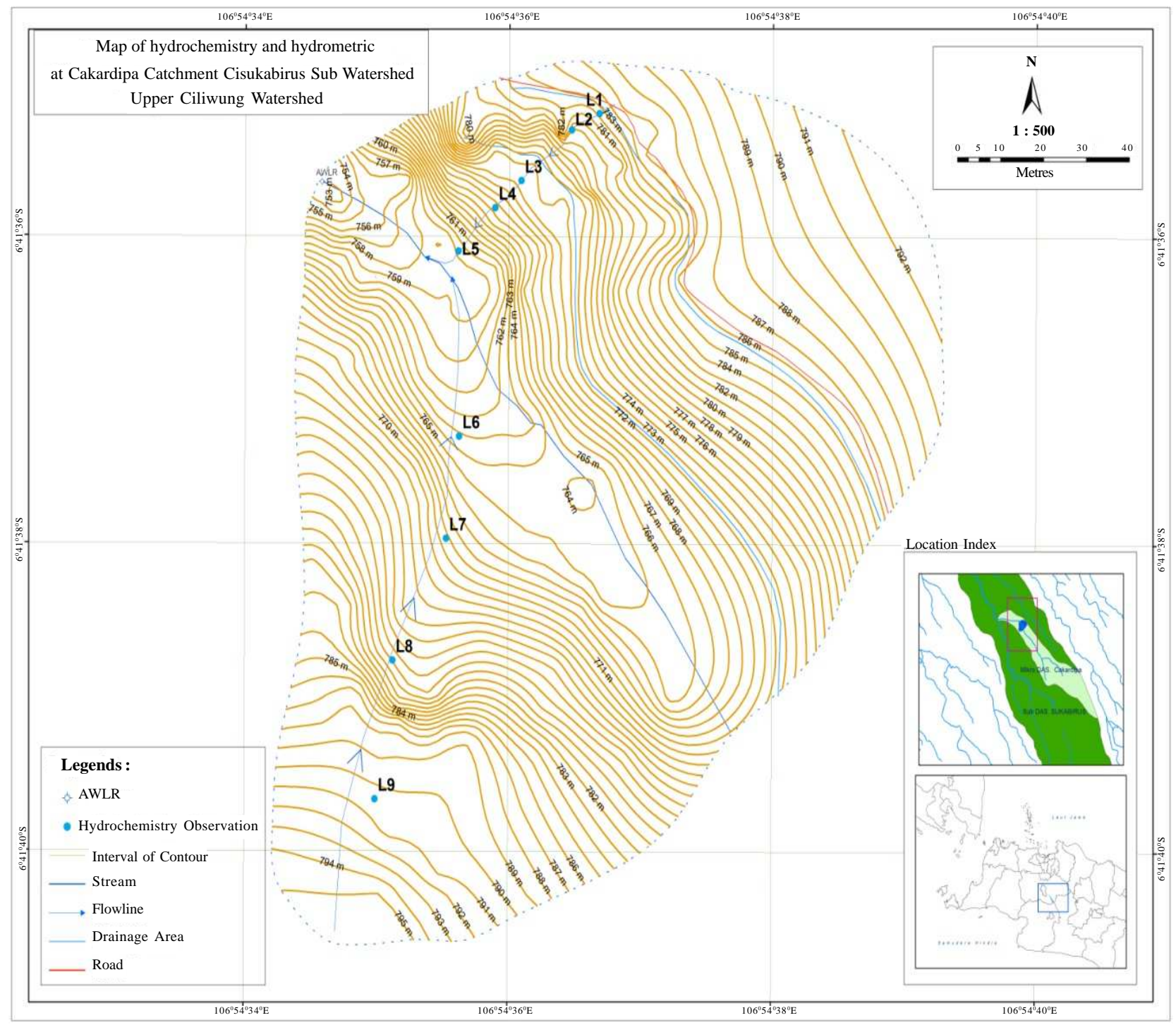

Figure 3. The nests of piezometers, tensiometers, and suction samplers by spatial at Cakardipa catchment, Cisukabirus Sub-watershed, Upper Ciliwung Watershed, Bogor, West Java

above the surface to avoid overland flow water from entering the piezometer. Since the groundwater samples were taken from the piezometer, it was covered by a PVC cup to avoid contamination from rain water. Soil water potential was measured using 2 tipe of tensiometer namely: (1) Mercury manometric tensiometer connected to a water column inside. The water column was a tube with inner diameter of $1.5 \mathrm{~cm}$ and outer diameter of 1.7 $\mathrm{cm}$ and the porous cup at the bottom of the tube, (2) Soil moisture meter tensiometer which was measured the water potensial with the porous cup at the bottom of the tube.

Suction samplers were used for sampling soil water. These samplers were PVC tubes with diameter of $2.25 \mathrm{~cm}$ complemented with porous cups at the bottom of the tubes, which were connected to $100 \mathrm{ml}$ flasks. To collect soil water, the flasks were vacuumed using a hand pump at a suction of about 40 bars. Depending upon the depths of bedrock, the thickness of soil mantle and the stratification of the soil horizon, samples were taken at various depths of $0.25,0.5,1.0,1.5,2.0,2.5,3.0$, 3.5, 4.0, 5.5, and $9 \mathrm{~m}$.

Groundwater, soil water, and stream water samples were collected monthly. Groundwater samples were taken from the piezometers (perforated at the bottom of $10 \mathrm{~cm}$ ), whereas soil water samples were collected from suction samplers installed at the same site with tensiometer nests at depths of $0.25,0.5,1.0,1.5,2.0$, and $4 \mathrm{~m}$. The stream water samples were taken at the upstream, middle, transect site, and near the weir. Samples were collected using $100 \mathrm{ml}$ polyethylene bottles. Before 
Table 1. Diagnostic Features Used to Determine Component Ranking (Evans and Davies 1998).

\begin{tabular}{clccc}
\hline Type & Rotational Direction & Curvature & Trend & Component Rankings \\
\hline C1 & Clockwise & Convex & N/A & $\mathrm{C}_{\mathrm{G}}>\mathrm{C}_{\mathrm{SO}}>\mathrm{C}_{\mathrm{R}}$ \\
$\mathrm{C} 2$ & Clockwise & Concave & Positive & $\mathrm{C}_{\mathrm{G}}>\mathrm{C}_{\mathrm{R}}>\mathrm{C}_{\mathrm{SO}}$ \\
$\mathrm{C} 3$ & Clockwise & Concave & Negative & $\mathrm{C}_{\mathrm{SO}}>\mathrm{C}_{\mathrm{G}}>\mathrm{C}_{\mathrm{R}}$ \\
A1 & Anticlockwise & Convex & N/A & $\mathrm{C}_{\mathrm{R}}>\mathrm{C}_{\mathrm{SO}}>\mathrm{C}_{\mathrm{G}}$ \\
A2 & Anticlockwise & Concave & Positive & $\mathrm{C}_{\mathrm{R}}>\mathrm{C}_{\mathrm{G}}>\mathrm{C}_{\mathrm{SO}}$ \\
A3 & Anticlockwise & Concave & Negative & $\mathrm{C}_{\mathrm{SO}}>\mathrm{C}_{\mathrm{R}}>\mathrm{C}_{\mathrm{G}}$ \\
\hline
\end{tabular}

collecting the samples, the bottles were rinsed with the groundwater, soil water or stream water depending upon the sampling sites. The water samples were analysed for $\mathrm{K}^{+}, \mathrm{Ca}^{2+}, \mathrm{Mg}^{2+}, \mathrm{Na}^{+}$, $\mathrm{SiO}_{2}, \mathrm{SO}_{4}^{2-}, \mathrm{NO}_{3}^{-}$, and $\mathrm{Cl}^{-}$.

\section{Hysteresis Loops}

The data for this study covered a time period of Juni 2009 through Mei 2010. There were 25 discharge measurements made during those years, and all measurements were in the units of liters per second $\left(\mathrm{L} \mathrm{sec}^{-1}\right)$. The discharge used for the C/Q hysteresis was on February 24, 2010. The solute concentrations used for the C/Q hysteresis in this study were $\mathrm{K}^{+}, \mathrm{Ca}^{2+}, \mathrm{Mg}^{2+}, \mathrm{Na}^{+}, \mathrm{SiO}_{2}, \mathrm{SO}_{4}^{2-}, \mathrm{NO}_{3}^{-}$, $\mathrm{Cl}^{-}$. The original datasets obtained from the Cakardipa catchment were edited to retrieve selected discharge data and water quality data. All maximum, minimum, and average values used in this study issued during the water years 2009 through 2010.

Analysis of component mixing and C/Q hysteresis can be studied with three component endmember system (3CM). This research explained that in systems where groundwater zone made a significant contribution and is chemically distinct, three end members should be used: groundwater $\left(\mathrm{C}_{\mathrm{G}}\right)$, soil water $\left(\mathrm{C}_{\mathrm{SO}}\right)$ and rain water $\left(\mathrm{C}_{\mathrm{R}}\right)$. In this case a three component mixing model was used: $\left(\mathrm{C}_{\mathrm{T}}=\mathrm{C}_{\mathrm{G}}+\mathrm{C}_{\mathrm{SO}}+\mathrm{C}_{\mathrm{R}}\right)$. If hysteresis loops were observed that were clockwise or anti-clockwise and convex, or if the hysteresis loops deviated from a linear mixing line, a need for a third component was implied (Evans and Davies, 1998). The C/Q hysteresis loops in this study was used a $3 \mathrm{CM}$ model, with three end members as follow: groundwater $\left(\mathrm{C}_{\mathrm{G}}\right)$, soil water $\left(\mathrm{C}_{\mathrm{SO}}\right)$ and rain water $\left(\mathrm{C}_{\mathrm{R}}\right)$. Table 1 describes all the component rankings for $3 \mathrm{CM}$.

\section{RESULTS AND DISCUSSION}

Stream water concentrations can be dynamic in periods of increasing discharge (Evans et al. 1998). Previously, it was thought that as discharge increased, chemical concentrations would decrease. This decreasing was believed to be a dilution of the groundwater chemicals by overland surface water. However, more studies had shown that C/Q hysteresis analysis was rarely linear, and that it was likely to produce a circular pattern from the differing concentrations on the rising and falling limbs (Walling and Webb 1986). This circular pattern was called a C/Q hysteresis loop.

The majority of the storm events produced hysteresis loops in a convex pattern, The pattern was highlighting the complex behaviors of solutes and discharge in different portions of a storm's hydrograph. In general, the type of hysteresis loop generated by an individual storm and that storm's respective component rankings were correlated in a predictable manner. The solutes that would be expected in the groundwater systems at Cakardipa mikrowatershed produced clockwise hysteresis loops, indicating a concentration component ranking was $\mathrm{C}_{\mathrm{G}}>\mathrm{C}_{\mathrm{SO}}>\mathrm{C}_{\mathrm{R}}$.

The analysis of the data, based on a majority of storm events during the water years 2009-2010, indicated that groundwater is the dominant water in the storms total discharge in respect to concentration levels. The solute concentrations $\left(\mathrm{K}^{+}, \mathrm{Ca}^{2+}, \mathrm{Mg}^{2+}\right.$, $\left.\mathrm{Na}^{+}, \mathrm{SiO}_{2}, \mathrm{SO}_{4}{ }^{2-}, \mathrm{NO}_{3}{ }^{-}, \mathrm{Cl}^{-}\right)$used for the $\mathrm{C} / \mathrm{Q}$ hysteresis then were plotted against discharge. Those data were combined with observed discharge by temporal and variation of solutes. Other investigators (Walling and Webb 1980) have also noted that rotational patterns for a given parameter within the same watershed will change from storm to storm. Observed discharge and concentration of solutes by C-Q diagram on February 14, 2010 storm event are presented in Figure 4 and 5. In general, concentration of solutes decreased on the rising limb of the hydrograph until during peak discharge and then increased on the falling limb.

The precise pattern varies from catchment to catchment and from storm to storm (Walling and Foster 1975). Applying previous work by Van Verseveld et al. (2008); Frey et al. (2007); Joerin 

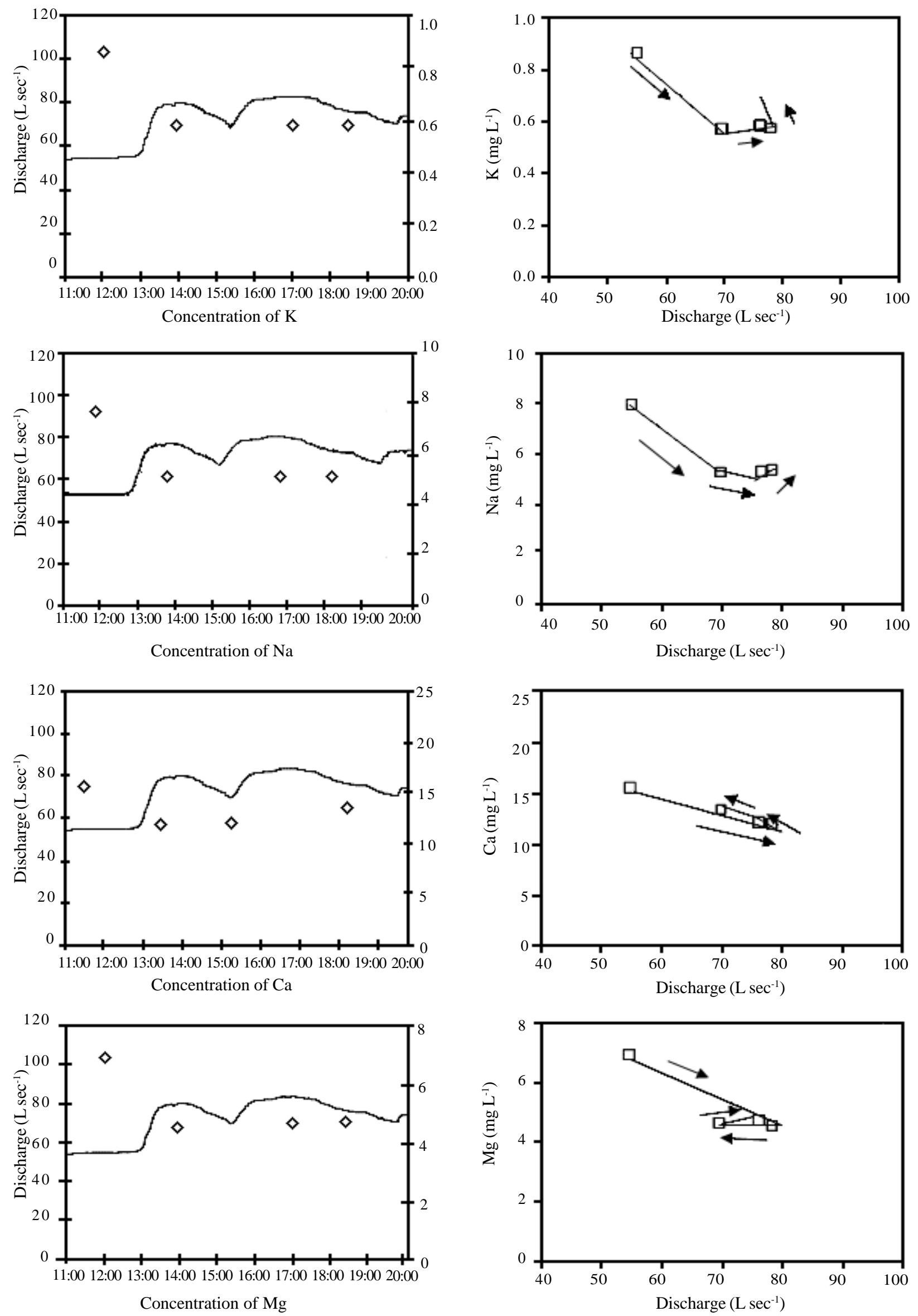

Figure 4. Discharge ( - ) and concentration ( $\diamond)$ of $\mathrm{K}, \mathrm{Na}, \mathrm{Ca}$, and $\mathrm{Mg}$ by temporal (left) and C-Q diagram (right) on February 14, 2010 storm event. 

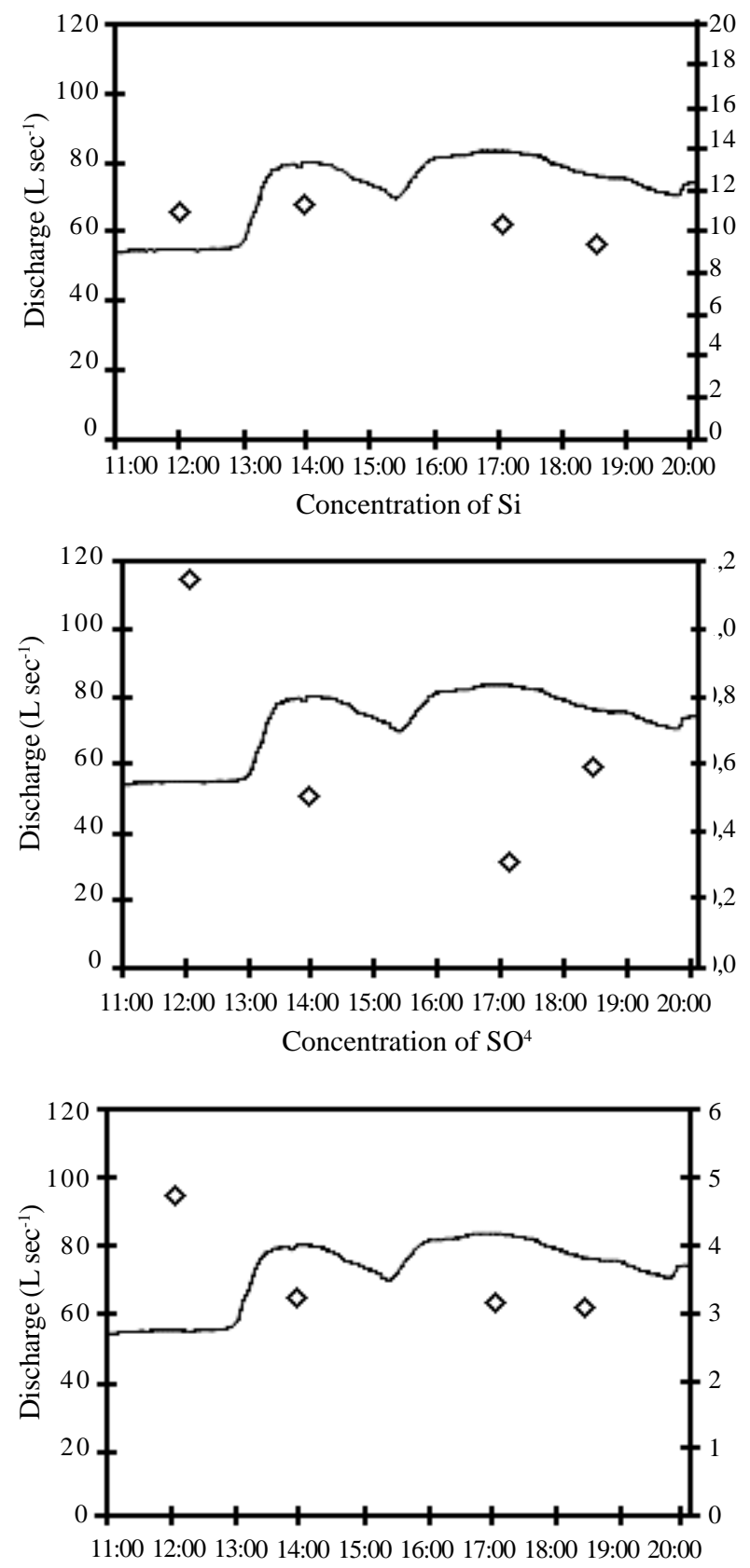

Concentration of $\mathrm{NO}^{3}$

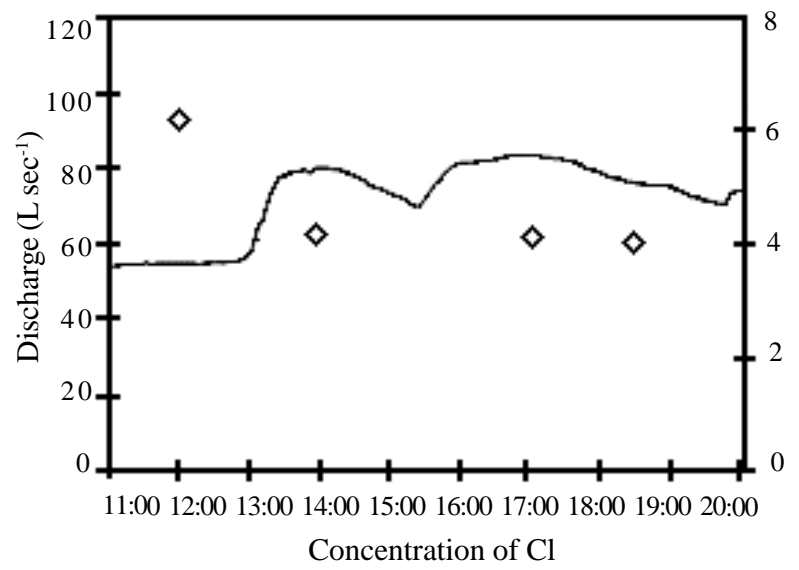

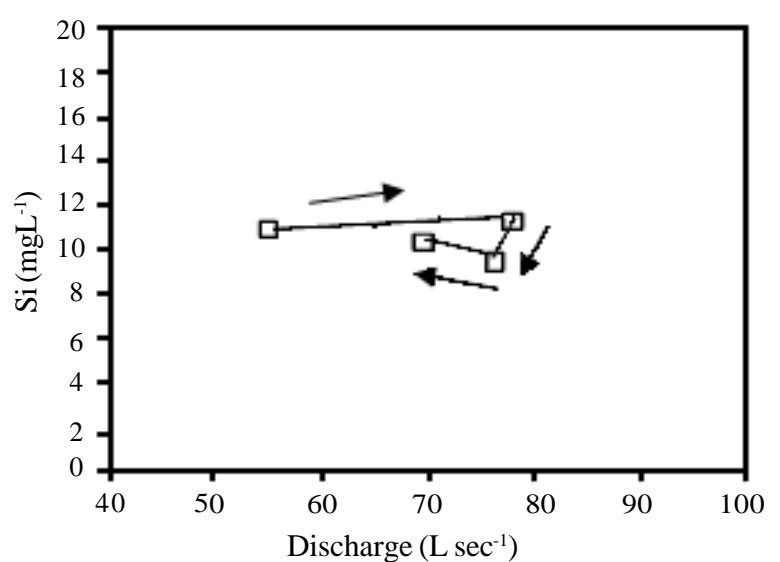
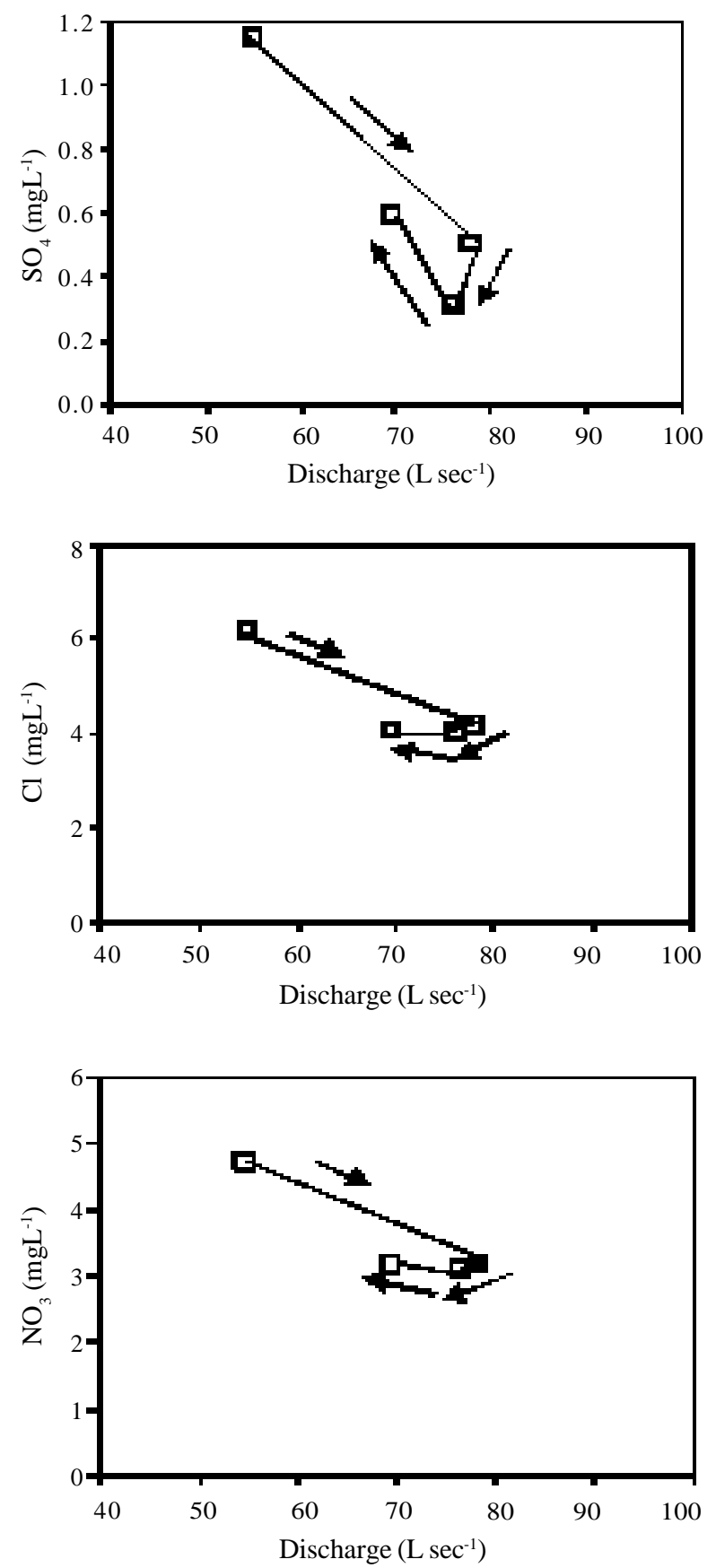

Figure 5. Discharge and concentration of $\mathrm{Si}, \mathrm{SO}_{4}, \mathrm{NO}_{3}$, and $\mathrm{Cl}$ by temporal (left) and C-Q diagram (right) on February 14, 2010 storm event. 


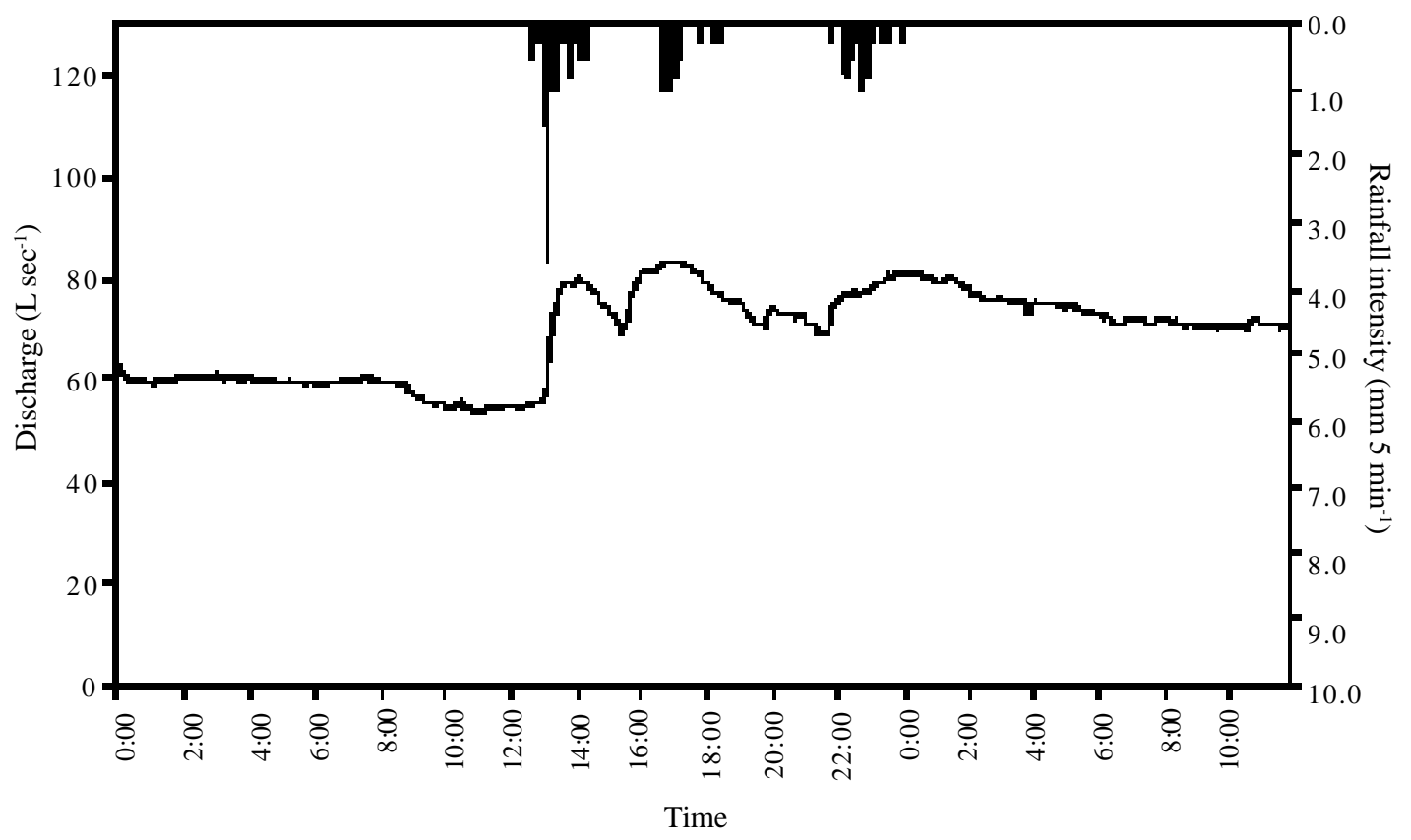

Figure 6. Rainfall intensity (-) and discharge (一)on February 14, 2010 storm event at Cakardipa catchment, Cisukabirus Subwatershed, Upper Ciliwung watershed.

et al. (2002); Burns et al. (2001), there were relationship between internal factors in catchment area (such as soil and solute) and stream chemistry. The total concentration levels of solutes at outlet varied by calculating and by modelling.

The solutes of $\mathrm{K}$ and Na produced concave curvature, anti-clockwise hysteresis loops, and positif trend, so that were classified as $\mathrm{A}_{2}$ loops with component ranking was $\mathrm{C}_{\mathrm{R}}>\mathrm{C}_{\mathrm{G}}>\mathrm{C}_{\mathrm{SO}}$. The solutes of $\mathrm{Mg}, \mathrm{SO}_{4}$ and $\mathrm{NO}_{3}$ which were assumed coming from groundwater produced concave curvature, clockwise hysteresis loops, and positive trend, indicating a concentration component ranking was $\mathrm{C}_{\mathrm{G}}>\mathrm{C}_{\mathrm{R}}>\mathrm{C}_{\mathrm{SO}}\left(\mathrm{C}_{2}\right.$ model $)$. While $\mathrm{Si}$ dan $\mathrm{Cl}$ produced convex curvature, clockwise hysteresis loops and non available trend, so that classified as C1loops with component ranking was $\mathrm{C}_{\mathrm{G}}>\mathrm{C}_{\mathrm{SO}}>\mathrm{C}_{\mathrm{R}}$.

The primary question that arises was whether the hysteresis patterns described above had any physical meaning in terms of the hydrological dynamics and mixing processes that might occur within this catchment. Any interpretation of hydrochemical dynamics based upon hysteresis patterns ultimately had a subjective element. Even relatively straightforward hysteresis patterns such as the C2 loops observed for this catchment were subject to multiple hydrological and hydrochemical interpretations, in this $\mathrm{C} 2$ loops had highest nutrient flushing among the models proposed by Evans and Davis (1998), while C3 loops was a medium, and A3 loops was the lowest. Rose (2003) showed that A3 hysteresis loops could be produced where event and soil water dominated the rising limb and soil and ground water dominated the falling limb of the hydrograph.

Based on a majority of storm events during the water years 2009-2010 in Cakardipa micro watershed, indicated that groundwater was the largest, followed by the soil water and rain water. There were positive trends in hysteresis loops indicated that the total concentration $\left(\mathrm{C}_{\mathrm{T}}\right)$ was consistently higher during the event at baseflow based on Evans at all and Davies $(1998 ; 1999)$ in previous study at Panola Watershed. The low $\mathrm{K}^{+}$ and $\mathrm{SO}^{-2}$ concentrations in groundwater at Cakardipa microwatershed had been atributed to the soil's ability to retain K and SO4-2. Peters (1994) stated that at Panola watershed besides retained by soils $\mathrm{SO}^{-2}$ those solute increased the concentration of soil water as a result of its mobilization in the surface, organic-rich, soil horizons. Besides that he noted that the $\mathrm{SO}_{4}^{-2}$ concentrations were higher in the runoff from the outcrop than in the corresponding precipitation, because the rainwater released the $\mathrm{SO}_{4}^{-2}$ that had been dry-deposited on the exposed bedrock.

Stream water concentrations can be dynamic in periods of increasing discharge (Evans et al. 1998). The surface runoff dominated the early storm event on the rising limb, followed by the contribution of soil water, and that ground water dominated the flow on the hygrograph's falling limb. Based on that Evans et al. (1998) and Chanat et al. 

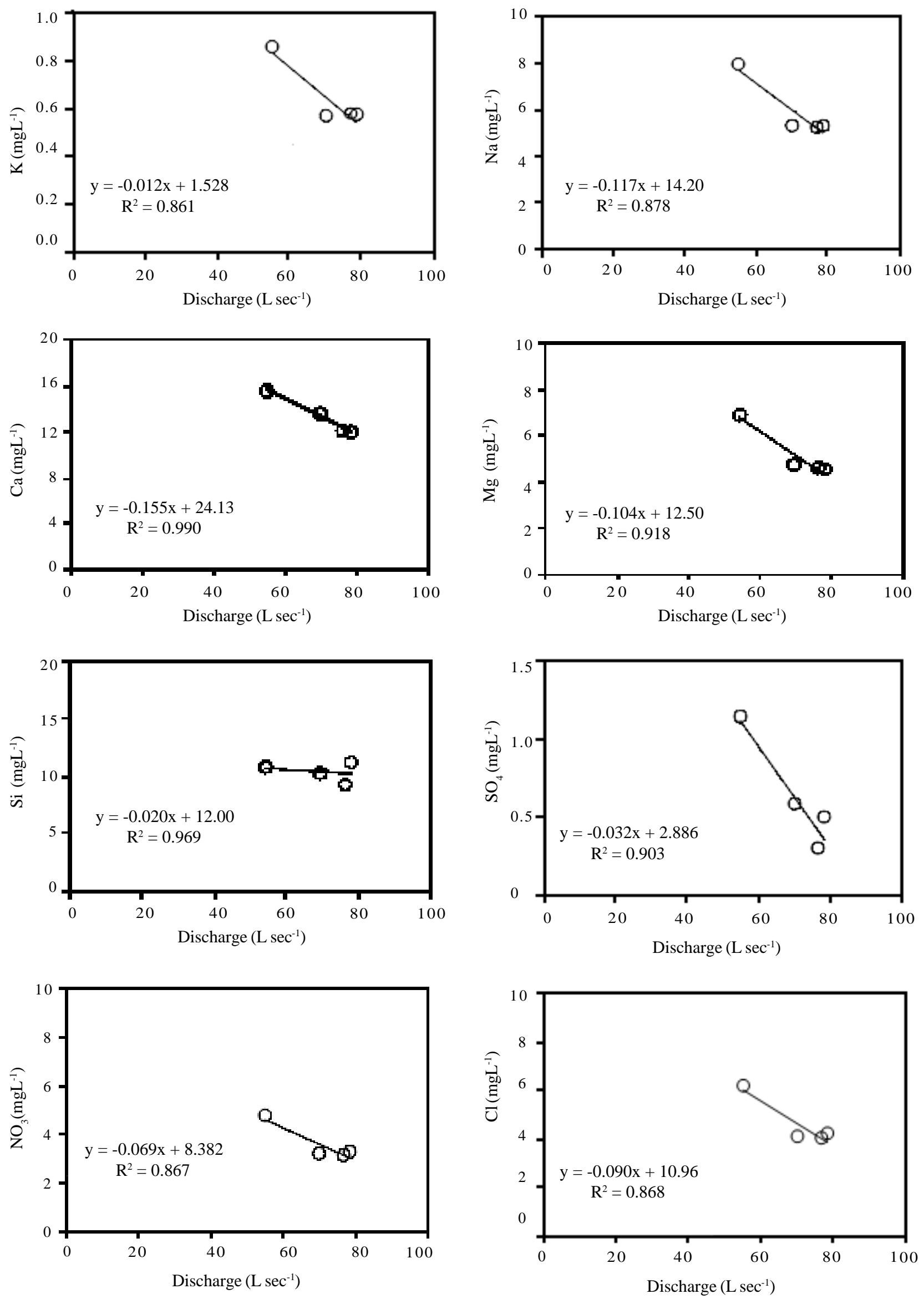

Figure 7. Relationships between cations anions and discharge on February 14, 2010 storm event. 
(2002) that Cakardipa system could follow a pattern like that system namely rain water as a source of surface water, soil water, and groundwater dominance. As depicted in Figure 4, it was thought that as discharge increased, chemical concentrations would decrease. This decreasing was believed to be a dilution of the groundwater chemicals by rain water. Hornberger et al. (2001) showed that it was possible to interpret solute-discharge hysteresis in terms of 'non-conservative' chemical dynamics, when reactions such as 'leaching/flushing' occur as quickly or quicker than the operative hydrological mixing processes. While in present study at Cakardipa found that $\mathrm{Ca}$ and $\mathrm{SO}_{4}$ were a conservative tracer to understand the flow path and chemical pathways in the headwater catchment.

At Cakardipa catchment concentration of phosphate was the lowest so it was eliminated from the concentration and discharge relationship analysis. While Haygrath et al. (2004) presented framework that provided a basis for development of a more complex and quantitative classification of concentration of phosporus and discharge $(\mathrm{Cp}-\mathrm{Q})$ relationship. The practical benefit of this approach is that it contributes to a dynamic modelling framework for helping to understand $\mathrm{P}$ transfer and delivery from slope to stream. Identified the importance of temporal approaches to $\mathrm{P}$ transfer could help as a guide for future understanding of mechanism that determine loads (Cp.Q). The other researches stated that solute daily series were generated by assuming a positive log-log relationship between solute concentration and discharge. This has been widely observed for nitrate, dissolved organic carbon (DOC) and phosphate (Moosmann et al. 2005). This relationship was caused by the mobilisation during rains of reactive solutes stored in forest and riparian top soils (Sickman et al. 2003; McGlynn and McDonnell 2003)

The three-component mixing analysis seems reasonable for the Cakardipa catchment and in some way is corroborated by the regression analyses. Although regression coefficients were not consistently high, they were between 0.069 until 0.99 . The low coefficients indicated by Si. Relationships between those cation and anion concentrations in the discharge and stream water during storm event on February 14, 2010 are depicted in Figure 6. These relationships were linier, within $\mathrm{K}, \mathrm{Na}, \mathrm{Ca}, \mathrm{Mg}, \mathrm{SO}_{4} \mathrm{NO}_{3}$, and $\mathrm{Cl}$ were highly correlated with discharge $\left(\mathrm{R}^{2}=0.861\right.$, $0.878,0.99,0.918,0.903,0.867,0.868$ respectively), while by $\mathrm{SiO}_{2}\left(\mathrm{R}^{2}=0.069\right)$ was not correlated.

\section{CONCLUSIONS}

Concentrations displayed hysteresis loops during most storm events, highlighting the complex relation among solutes and discharge during storm hydrographs. The solutes that had the highest concentrations in groundwater at Cakardipa catchment were $\mathrm{Na}, \mathrm{Ca}$, and $\mathrm{SiO} 2$.

The solutes of $\mathrm{K}$ and $\mathrm{Na}$, produced concave curvature, anti-clockwise hysteresis loops, and positif trend, so that classified as $\mathrm{A}_{2}$ loops with component ranking was $\mathrm{C}_{\mathrm{R}}>\mathrm{C}_{\mathrm{G}}>\mathrm{C}_{\mathrm{SO}}$. The solutes of $\mathrm{Mg}, \mathrm{SO}_{4}$, and $\mathrm{NO}_{3}$ which were assumed coming from groundwater produced concave curvature, clockwise hysteresis loops, and positive trend, indicating a concentration component ranking was $\mathrm{C}_{\mathrm{G}}>\mathrm{C}_{\mathrm{R}}>\mathrm{C}_{\mathrm{SO}}\left(\mathrm{C}_{2}\right.$ model $)$. While $\mathrm{Si}$ dan $\mathrm{Cl}$ produced convex curvature, clockwise hysteresis loops and non available trend, so that classified as C1loops with component ranking is $\mathrm{C}_{\mathrm{G}}>\mathrm{C}_{\mathrm{SO}}>\mathrm{C}_{\mathrm{R}}$.

The solutes that would be expected in the groundwater systems at Cakardipa microwatershed produced anti clockwise hysteresis loops, indicating a concentration component ranking of $\mathrm{C}_{\mathrm{G}}>\mathrm{C}_{\mathrm{SO}}>$ $\mathrm{C}_{\mathrm{R}}$. In general, concentration of solutes decreased on the rising limb of the hydrograph until during peak discharge and then increased on the falling limb.

\section{REFFERENCES}

Bernal S, A Butturini and F Sabater. 2006. Inferring nitrate sources through end member mixing analysis in an intermittent Mediterranean stream. Biogeochemistry 81 (3): 269-289. doi: 10.1007/s105-006-9041-7.

Burns DA, JJ McDonnell, RPHooper, NE Peters, JE Freer, C Kendall and K Beven. 2001. Quantifying contributions to storm runoff through end-member mixing analysis and hydrologic measurements at the Panola Mountain Research Watershed (Georgia, USA). Hydrol Process 15: 1903-1924. doi: 10.1002/ hyp. 246.

Caroll KP, S Rose and NE Peters. 2007. Concentration/ discharge hysteresis analysis of storm events at the Panola Mountain research watershed, Georgia, USA. In: AP Georgakakos (ed). Proceedings of Georgia Water Resources Conference, March 2729, 2007. Georgia Water Resources Institute, Georgia Institute of Technology, Atlanta, Georgia.

Chanat JG, KC Rice and GM Hornberger. 2002. Consistency of patterns of concentration-discharge plots. Water Resour Res 38 (8): 1147. doi:10.1029/ 2001WR000971.

Evans C and TD Davies. 1998. Causes of concentration/ discharge hysteresis and its potential as a tool for analysis of episode hydrochemistry. Water Resour Res 34 (1): 129-137. doi: 10.1029/97WR01881. 
Evans C, TD Davies and PS Murdoch. 1999. Component flow processes at four streams in the Catskill Mountains, New York, analysed using episodic concentration/discharge relationships. Hydrol Process 13 (4): 563-575. doi: 10.1002/(SICI)10991085(199903)13:4.

Frey KE, DI Siegel and LC Smith. 2007. Geochemistry of west Siberian streams and their potential response to permafrost degradation. Water Resour Res 43 W03406: 1-15. doi: 10.1029/2006WR004902,2007.

Haygrath P, BL Turner, A Fraser, S Jarvis, T Harrod, D Nash, D Halliwell, T Page and K Beven. 2004. Temporal variability in phosphorus transfers: classifying concentration-discharge event dynamics. Hydrol Earth Syst Sci 8 (1): 88-97.

Hornberger GM, TM Scanlon and JP Raffensperger. 2001. Modelling transport of dissolved silica in a forested headwater catchment: the effect of hydrological and chemical time scales on hysteresis in the concentration-discharge relationship. Hydrol Process 15 (10): 2029-2038. doi: 10.1002/hyp. 254.

Hinton MJ, SL Schiff and MC English. 1994. Examining the contributions of glacial till water to storm runoff using two and three component hydrograph separation. Water Resour Res 30 (4): 983-993.

Hooper RP, N Christophersen and NE Peters. 1990. Modelling streamwater chemistry as a mixture of soilwater end members: An application to the Panola Mountain watershed, Georgia, USA. J Hydrol 116: 321-343. doi: 10.1016/0022-1694(90)9011-G.

Joerin C, KJ Beven, I Iorgulescu and A Musy. 2002. Uncertainty in hydrograph separation based on geochemical mixing models. J Hydrol 255: 90-106. doi: 10.1016/S0022-1694(01)00509-1.

Kennedy VC, C Kendall, GE Zellweger, TA Wyerman and RJ Avanzino. 1986. Determination of the components of stormflow using water chemistry and environmental isotopes, Mattole River basin, California. J Hydrol 84 (1-2): 107-140. doi: 10.1016/ 0022-1694(86)90047-8.
Moosmann L, B Muller, R Gachter, A Wuest, E Butscher and P Herzog. 2005. Trend-oriented sampling strategy and estimation of soluble reactive phosphorus loads in streams. Water Resour Res 41: W01020: 1-10. doi: 10.1029/2004WR003539.

McGlynn BL and JJ Mc Donnell. 2003. The role of discrete landscape units in controlling catchment dissolved organic carbon dynamics. Water Resour Res 39, 1090: 1-18. doi:10.1029/2002WR001525.

Peters NE. 1994. Water-quality variations in a forested Piedmont catchment, Georgia, USA. J Hydrol 156: 73-90. doi: 10.1016/0022-1694(94)90072-8.

Rose S. 2003. Comparative solute-discharge hysteresis analysis for an urbanized and a 'control basin' in the Georgia (USA) Piedmont. J Hydrol 284: 45-56. doi: 10.1016/j.jhydrol.2003.07.001.

Sickman JO, A Leydecker, CCY Chang, C Kendall, JM Melack, DM Lucero and J Schimel. 2003. Mechanisms underlying export of $\mathrm{N}$ from high elevation catchment during seasonal transitions. Biogeochemistry 64:1-24. doi: 10.102/ A:1024928317057.

vanVerseveld WJ, JJ McDonnell and K Lajtha. 2008. Mechanistic assessment of nutrient flushing at the catchment scale. J Hydrol 58: 268-287. doi: 10.1016/j.jhydrol.2008.06.009.

Walling DE and BW Webb. 1980. The spatial dimension in the interpretation of stream solute behavior. $J$ Hydrol 47: 129-149. doi: 10.1016/00221694(80)90052-9.

Walling DE and IDL Foster. 1975. Variations in the natural chemical concentration of river water during flood flows, and the lag effect:Some further comments. J Hydrol 26: 237-244. doi: 10.1016/00221694(75)90005-0.

Walling DE and Webb BW. 1986. Solute Processes. John-Wiley \& Sons, New York. pp. 251-316. 